\title{
Poultry blood from slaughterhouses: development of a biopreservation system to improve microbiological quality prior to transforming it into by-products
}

M. V. Zbrun, L. S. Frizzo, L.P. Soto, M. R. Rosmini, G. J. Sequeira, D. M. Astesana, J. E. Blajman, E. Rossler, A. Berisvil, A. Romero Scharpen \& M. L. Signorini

To cite this article: M. V. Zbrun, L. S. Frizzo, L.P. Soto, M. R. Rosmini, G. J. Sequeira, D. M. Astesana, J. E. Blajman, E. Rossler, A. Berisvil, A. Romero Scharpen \& M. L. Signorini (2016): Poultry blood from slaughterhouses: development of a biopreservation system to improve microbiological quality prior to transforming it into by-products, British Poultry Science, DOI: 10.1080/00071668.2016.1206192

To link to this article: http://dx.doi.org/10.1080/00071668.2016.1206192

Accepted author version posted online: 28 Jun 2016.

Published online: 28 Jun 2016.

Submit your article to this journal

山ll Article views: 2

Q View related articles $\sqsubset$

View Crossmark data \lceil 
PUBLISHER: TAYLOR \& FRANCIS \& BRITISH POULTRY SCIENCE LTD JOURNAL: BRITISH POULTRY SCIENCE

DOI: $10.1080 / 00071668.2016 .1206192$

\section{CBPS-2016-060}

Ed. Kjaer, June 2016;

Edited Hocking 20 June 2016

Poultry blood from slaughterhouses: development of a biopreservation system to improve microbiological quality prior to transforming it into by-products

M. V. ZBRUN ${ }^{1,2^{*}}$, L. S. FRIZZO ${ }^{1,2}$, L.P. SOTO ${ }^{1,2}$, M. R. ROSMINI ${ }^{2,3}$, G. J. SEQUEIRA ${ }^{2}$, D.

M. ASTESANA 1 , J. E. BLAJMAN ${ }^{1}$, E. ROSSLER ${ }^{2}$, A. BERISVIL ${ }^{1}$, A. ROMERO

SCHARPEN $^{1}$ AND M. L. SIGNORINI ${ }^{2,4}$

Running title: Development of a biopreservation system for poultry blood

Accepted for publication $18^{\text {th }}$ May 2016 
${ }^{1}$ Food Analysis Laboratory, Institute of Veterinary Sciences-National Council of Scientific and Technical Research (ICIVET-CONICET/UNL), ${ }^{2}$ Department of Veterinary Public Health (DSPV). Faculty of Veterinary Science, Litoral National University, Santa Fe, ${ }^{3}$ Faculty of Agricultural Science, Catholic University of Córdoba, Province of Córdoba and ${ }^{4}$ National Council of Scientific and Technical Research, Agricultural Technology Institute National (EEA) Rafaela, Argentina

Correspondence to: M. V. Zbrun, Kreder 2805, (S3080HOF) Esperanza, Provincia de Santa Fe, Argentina. E-mail virginiazbrun@yahoo.com.ar

\footnotetext{
Abstract. 1. The aim of this study was to investigate the use of indigenous lactic acid bacteria (LAB) with specific additives as a Biopreservation System (BS) for poultry blood during its storage in slaughterhouses.

2. The BS consisted of two LAB (Enterococcus faecalis DSPV 008SA or Lactobacillus salivarius DSPV 032SA) with 4 additives (lactose $2 \mathrm{~g} / 1$, yeast extract $0.4 \mathrm{~g} / 1$, ammonium citrate $0.4 \mathrm{~g} / \mathrm{l}$ and $\mathrm{NaCl} 1 \mathrm{~g} / \mathrm{l}$ ). After $24 \mathrm{~h}$ storage at $30^{\circ} \mathrm{C}$, lower counts of enterobacteria, coliforms, Pseudomonas spp. and Staphylococcus aureus were evident in blood treated with the BS than in untreated blood.

3. The ability of LAB to prevent haemolysis was evident. A decrease in $\mathrm{pH}$ was associated with control of spoilage microorganisms but it needed to be regulated to prevent coagulation of proteins.

4. On the basis of these results it is worthwhile to supplement blood with a BS to avoid undesirable changes during blood storage before processing.
} 


\section{INTRODUCTION}

In Argentina, the number of poultry slaughtered each year is more than 734 million (MinAgri, 2013), producing almost 150 million 1 of blood which potentially could be collected for industrial applications. Poultry blood is considered to be an important source of high-quality protein, because of its high isoleucine and lysine content (Márquez et al., 2005). Due to excellent nutritional qualities and functional properties, poultry blood has been considered a by-product which can be used as a raw material for both the feed and food industries (Ockerman and Hansen, 1988; Dávila et al., 2006).

The use of animal blood proteins is important considering the high levels of protein deficiencies around the world. However, poultry blood is not collected and handled properly at slaughterhouses and generally is of poor quality as it becomes contaminated by spoilage and pathogenic microorganisms from the feathers, skin and guts of slaughtered animals (Dávila et al., 2006). Also, blood is usually stored without refrigeration and in such conditions foodborne spoilage microorganisms and pathogens readily grow and reduce the opportunities for processing (Dávila, 2006; Zbrun et al., 2013a).

Blood biopreservation using lactic acid bacteria (LAB) could be a valuable biotechnological tool. LAB are used in other areas of food production because of their proven ability to inhibit the growth of undesirable bacteria (De Vuyst and Vandamme, 1994; Signorini et al.,2006; Zbrun et al., 2013a) through a wide variety of mechanisms (Lindgren and Dobrogosz, 1990; Hugas, 1998; O’Sullivan et al., 2002). Dávila et al. (2006)

demonstrated that supplementation of porcine blood with inulin and inoculation with an active LAB strain could prevent undesirable changes during chill storage, especially useful in preventing the effects of a cold-chain breakdown.

Zbrun et al. (2013) identified and isolated two LAB from poultry blood obtained from industrial slaughterhouses, which exhibited ability to grow in blood and inhibit the growth of undesirable microorganisms. The aim of this study was to investigate the use of these 
indigenous LAB and other additives as a blood biopreservative system (BS) against spoilage microbiota, and to determine its impact on blood $\mathrm{pH}$ and haemolysis during storage at $30^{\circ} \mathrm{C}$.

\section{MATERIALS AND METHODS}

\section{Confirmation of the Biopreservation System}

Ninety-six different LAB, isolated from avian blood obtained in slaughterhouses, were investigated for their antimicrobial activity and ability to grow in blood (Zbrun et al., 2013). Enterococcus faecalis DSPV008SA was selected because it produced a substance similar to bacteriocin. It showed antagonistic activity against Salmonella brandenburg, Salmonella ssp. SA (isolated from slaughterhouse avian blood) and Pseudomonas aeruginosa SA grown in agar plates (Zbrun et al., 2013). Lactobacillus salivarius DSPV032SA was selected because in earlier studies (Zbrun, 2014) it demonstrated a high ability to grow in blood.

Both Enterococcus faecalis DSPV008SA and Lactobacillus salivarius DSPV032SA were homofermentative and unable to degrade arginine, which are useful characteristics for the biopreservation of blood. Homofermentative bacteria are incapable to produce $\mathrm{CO}_{2}$, a gas that produce adverse effects during the production. Arginine is a biogenic amine and could cause harmful health effects.

Thermal stability of both strains was evaluated to ensure the lethality of the microorganisms after high temperature treatment. In a previous study (Zbrun, 2014) it was demonstrated that treatment at $65^{\circ} \mathrm{C}$ for $7.5 \mathrm{~min}$ was lethal for both strains. This result implies that when slaughterhouse blood is processed in the industry by spray drying at $>300^{\circ} \mathrm{C}$ the strains of BS will not survive. The selected LAB strains were stored at $-80^{\circ} \mathrm{C}$ with $20 \%$ glycerol in $2 \mathrm{ml}$ vials $(8 \log \mathrm{cfu} / \mathrm{ml})$.

In addition, the blood was enriched with the aim of improving LAB growth. In previous studies (Zbrun, 2014) the effect of different concentrations of additives was evaluated individually for each strain. In this way, the concentration of additives that affected 
spoilage bacteria and improved growth of the Enterococcus faecalis DSPV008SA and Lactobacillus salivarius DSPV032SA was selected for using in the BS. The optimum concentration of each additive was determined: $2 \mathrm{~g} / 1$ bacteriological lactose, $0.4 \mathrm{~g} / 1$ yeast extract, $0.4 \mathrm{~g} / 1$ ammonium citrate and $1 \mathrm{~g} / 1$ sodium chloride.

\section{Antagonistic effects of the Biopreservation System against spoilage bacteria present in}

\section{slaughterhouse blood}

Experimental design: Blood samples were obtained during the slaughter of poultry in industrial abattoirs. They were collected in sterile containers $(250 \mathrm{ml})$ containing glass beads for defibrination as blood was draining from the animals during bleeding in an open collection system. Containers were maintained at chilled temperatures $\left(<5^{\circ} \mathrm{C}\right.$ on ice $)$ and immediately transported to the laboratory. At the laboratory, blood samples were divided into two, one to be used as untreated control (non-inoculated) and the other treated with the BS. Five replicates of the experiment were performed.

\section{Blood inoculation}

Enterococcus faecalis DSPV 008 SA and L. salivarius DSPV 032 SA cultures were grown separately to the stationary phase in MRS broth (Oxoid, United Kingdom) for $24 \mathrm{~h}$ at $37^{\circ} \mathrm{C}$ in an anaerobic atmosphere. After centrifugation at $10,000 \mathrm{~g}$ for $10 \mathrm{~min}$, the supernatant was discarded and the bacterial cells were re-suspended in slaughterhouse blood in order to obtain a concentration around $10^{8} \mathrm{cfu} / \mathrm{ml}$ for each bacteria. Then, sterile solutions of bacteriological lactose, yeast extract, ammonium citrate and sodium chloride were added to the suspensions described above.

Control blood and blood with BS treatments were maintained at a constant temperature of $30^{\circ} \mathrm{C}$ for $48 \mathrm{~h}$. During the storage period, the $\mathrm{pH}$ of the samples inoculated with the $\mathrm{BS}$ was regulated $(\mathrm{pH}=6.0)$ at 6,12 , and $24 \mathrm{~h}$ by adding a sterile solution of $2 \mathrm{M}$ $\mathrm{NaOH}$. Samples of $5 \mathrm{ml}$ were removed from containers at different times $(0,24$ and $48 \mathrm{~h}$ of 
storage), and used for: microbiological counts, haemolysis measurement and $\mathrm{pH}$ measurement.

\section{Microbiological measurements}

Microbiological populations were counted in the specific media (Zamora, 2003). Samples were serially diluted in sterile peptone water (peptone $2 \mathrm{~g}$ and $\mathrm{NaCl} 7.5 \mathrm{~g} / \mathrm{l}$ ) and were plated in duplicate. In control and inoculated blood indicator bacteria were determined. The Enterobacteriaceae species were determined in violet red bile glucose agar (VRBG, Oxoid, United Kingdom) at $37^{\circ} \mathrm{C}$ for $24 \mathrm{~h}$. Violet red bile lactose agar (VRBL, Oxoid, United Kingdom) was used for coliform enumeration after incubation at $44^{\circ} \mathrm{C}$ for 24 h. Pseudomonas spp. was determined in Pseudomonas cetrimide agar (Oxoid, United Kingdom), and S. aureus in mannitol salt agar (Oxoid, United Kingdom), both media being incubated at $37^{\circ} \mathrm{C}$ for $48 \mathrm{~h}$. MRS agar (Oxoid, United Kingdom) was used for LAB enumeration and was incubated anaerobically for $72 \mathrm{~h}$ at $37^{\circ} \mathrm{C}$.

\section{pH and haemolysis analysis}

The $\mathrm{pH}$ of control and inoculated blood was monitored with a $\mathrm{pH}$ meter (Altronix, U.S.A.) using a 2-ml samples of blood. Haemolysis was determined because it is considered to be a useful indicator of industrial blood quality. Plasma was obtained by centrifuging ( $2250 \mathrm{~g}$ for $15 \mathrm{~min}$ at $4^{\circ} \mathrm{C}$ ) and decanting. The increase in haemolysis was determined by measuring the absorbance at $414 \mathrm{~nm}$ using a spectrophotometer (Jenway, United Kingdom) with a 1:5 dilution of the plasma samples (Dávila et al., 2006).

\section{Statistical analysis}

The variables (microbiological counts, $\mathrm{pH}$ and haemolysis) were analysed using ANOVA. Differences between treatment means for each variable at each time were tested for significance using Student's t-test. The level of significance was set at $P<0.05$ and the normal distribution and the homogeneity of variances were checked. All statistical analyses 
were done using the software package InfoStat (Universidad Nacional de Córdoba, Argentina).

\section{RESULTS}

\section{The antagonistic effect of the BS on blood}

Counts of Enterobacteriaceae and coliforms in blood samples at the beginning of the experiment were $5.5 \log \mathrm{cfu} / \mathrm{ml}$ and $5.2 \log \mathrm{cfu} / \mathrm{ml}$, respectively, while the numbers of Pseudomonas spp. and S. aureus were $2.5 \log \mathrm{cfu} / \mathrm{ml}$ and $4.5 \log \mathrm{cfu} / \mathrm{ml}$, respectively. Table 1 shows the antagonistic capacity of the BS against spoilage bacteria when the blood was stored at $30^{\circ} \mathrm{C}$. The poultry blood treated with the BS had the lowest counts of all spoilage microorganisms throughout the study $(P<0.05)$.

Table 1 near here

Populations of Enterobacteriaceae, coliforms, and Pseudomonas spp. had similar growth patterns. During the first $24 \mathrm{~h}$ of storage the BS was able to inhibit the growth of these spoilage microorganisms. The blood without the BS had higher counts (approximately $3 \log$ $\mathrm{cfu} / \mathrm{ml})$ than the blood inoculated with the BS $(P<0.001)$. During the last $24 \mathrm{~h}$ of storage at $30^{\circ} \mathrm{C}$, the microbial levels of all groups showed an increase. In the treated blood the final levels of Enterobacteriaceae and coliforms were not significantly different from those in untreated blood. However, the blood inoculated with the BS showed significantly lower $(P<$ 0.05 ) counts of Pseudomonas spp. even after $48 \mathrm{~h}$ of storage at $30^{\circ} \mathrm{C}$.

The bacterial growth of $S$. aureus followed a different pattern (Table 1). During the first $24 \mathrm{~h}$ of storage counts increased approximately $1.5 \mathrm{log} \mathrm{cfu} / \mathrm{ml}$ in untreated blood. In contrast, the counts of $S$. aureus showed a reduction of $2.3 \log \mathrm{cfu} / \mathrm{ml}$ at this time in the BStreated blood. During the last $24 \mathrm{~h}$ of storage at $30^{\circ} \mathrm{C}$, the levels of these bacteria were similar in both blood treatments $(P=0.10)$.

Regarding the LAB counts, the initial value in untreated blood was $4.99 \log \mathrm{cfu} / \mathrm{ml}$, increasing $3.0 \log \mathrm{cfu} / \mathrm{ml}$ after $24 \mathrm{~h}$ storage at $30{ }^{\circ} \mathrm{C}$. This indicates that the blood had native LAB with the ability to grow in the slaughterhouse blood. However, the untreated blood never 
reached the $\mathrm{LAB}$ count observed in treated blood. This growth of native LAB may be beneficial for preserving blood, but seems not to be effective enough to extend the life of the blood at the slaughterhouse. Furthermore, the treated blood LAB count remained stable throughout the storage period and was higher than untreated blood count $(P<0.001)$. Furthermore, these results indicate that almost all LAB present in the treated blood belonged to the BS. The presence of BS LAB might be beneficial to the blood preservation because these bacteria were studied and previously characterised for this purpose.

\section{Analysis of pH and haemolysis}

All through the experiment, the $\mathrm{pH}$ was different in the two treatments $(P<0.001)$. The blood treated with the BS had a lower $\mathrm{pH}$ level (6.0) at the beginning of the experiment than blood without BS, decreasing to 4.6 after $24 \mathrm{~h}$ of incubation at $30^{\circ} \mathrm{C}$. At the end of the experiment, the BS-treated blood showed an increase, reaching a value of 6.7. It is important to mention that the $\mathrm{pH}$ was adjusted twice (at $12 \mathrm{~h}$ and $24 \mathrm{~h}$ of storage) to prevent protein coagulation. On the other hand, the untreated blood had a $\mathrm{pH}$ of 7.6 at the beginning of the experiment, which decreased by 0.7 after $24 \mathrm{~h}$ incubation, reaching a final value of T/abl(ब2bitear here 2).

Regarding the level of haemolysis, during storage at $30^{\circ} \mathrm{C}$ the blood stored without the BS exhibited red blood cell rupture with a consequent increase in absorbance (Table 3). By contrast, the blood with BS treatment maintained the same absorbance values throughout storage. At the beginning of the storage period, both blood treatments had similar absorbance values $(P=0.413)$ but after $24 \mathrm{~h}$ and $48 \mathrm{~h}$, the absorbance of untreated blood increased threefold from the initial value ( $P=0.057$ for $24 \mathrm{~h}$ and $P=0.037$ for $48 \mathrm{~h}$ ) (Table 3 ). 


\section{DISCUSSION}

The ability of LAB to inhibit or at least counteract the negative effects of food spoilage bacteria has been much studied (Holzapfel et al., 1995; Ross et al., 2002), but not evaluated using slaughterhouse by-products. In this study the development of a novel biopreservative system was investigated. This system included two LAB and 4 additives and aimed to preserve poultry blood obtained from slaughterhouses and stored at $30^{\circ} \mathrm{C}$ (simulating a high environmental temperature).

The results suggest that the BS was able to prevent the growth of spoilage bacteria during the first $24 \mathrm{~h}$ of storage at $30^{\circ} \mathrm{C}$. Also, the level of haemolysis in blood with the $\mathrm{BS}$ remained unchanged during $48 \mathrm{~h}$, indicating that the BS prevented the rupture of red blood cells.

One of the possible mechanisms that could explain the biopreservative effect is the lactic acid production by LAB. The homolactic fermentation by LAB produces lactic acid almost exclusively. This lowers $\mathrm{pH}$ and it has bacteriostatic action which inhibits most pathogenic bacteria (Schillinger and Lucke, 1990). In this way, the decrease in intracellular $\mathrm{pH}$ alters the membrane structure and leads to a decrease in the activity of several enzymes that are pH-sensitive (Shelef, 1994; Cotter and Hill, 2003; Signorini et al., 2006).

However, the control of the $\mathrm{pH}$ level in the blood during storage is extremely important because it is necessary to maintain the inhibitory action on spoilage bacteria but not too low to generate coagulation of the proteins. In this way, the $\mathrm{pH}$ regulation at $12 \mathrm{~h}$ allowed optimum LAB growth without affecting protein coagulation.

Another mechanism associated with LAB as biopreservative agents is related to the growth rates and the competitiveness for nutrients, which produces a selective advantage over slower growing competitors (Bredholt et al., 1999). Also, the inhibition of spoilage bacteria by LAB may be due to numerous mechanisms such as the production of hydrogen peroxide or 
other antimicrobial substances such as bacteriocins (Schillinger and Lucke, 1990; Daeschel, 1992; Skytta et al., 1993; Vandenbergh, 1993).

Also, the biopreservative properties could be associated with the addition of other inhibitory substances such as sodium chloride and ammonium citrate. Sodium chloride is one of the oldest and most common agents used for food preservation. The salt concentration in fermented products inhibits the growth of many undesirable microorganisms and promotes the growth of more salt tolerant lactic acid bacteria (Kołozyn-Krajewskaa and Dolatowski, 2012). The potential of $\mathrm{LAB}$ to tolerate salt is one of the challenges for the fermentation process. In this way, LAB of BS have been tested against different concentrations of ammonium citrate and sodium chloride previously (Zbrun, 2014). Furthermore, the results of several studies show that the viability of bacteria in a fermented product matrix is strain-dependent (Cogan et al., 2007; Santivarangkna et al., 2008). In the same way, ammonium citrate has a recognised capacity for inhibiting gram-negative bacteria and is used in several culture media. For that reason, this substance could be related to the limited growth of spoilage bacteria.

All of the possible inhibitory mechanisms mentioned above could directly affect the spoilage bacteria being studied here. However, S. aureus has special characteristics as it is resistant in low $\mathrm{pH}$ and halotolerant media. Studies showed a direct correlation between medium acidification and the level of $S$. aureus inhibition (impact on growth rate or survival) (Barber and Deibel, 1972; Metaxopoulos et al., 1981), although this inhibitory effect can be modified according to media composition and totally abolished if culture conditions are changed (Daly et al., 1972). On the whole, in the current study, the data showed that LAB activity can have different impacts on $S$. aureus growth depending on the media considered. The effect of inoculation with LAB on blood haemolysis was also evaluated. The haemoglobin content may be responsible for off-flavours and discolouration of slaughterhouse blood (Lynn Knipe, 1988). The haemoglobin content in the plasma fraction increased in blood without BS, while in samples inoculated with BS the haemolysis value 
remained constant. Therefore, no loss in this parameter of plasma quality could be observed in the blood with the BS. The results agree with those at refrigeration temperatures reported by Dávila et al. (2006).

On the basis of these results, supplementing blood with a BS to avoid undesirable changes during storage prior to processing is recommended that. The BS provides a useful protective system even under an ambient temperature of $30^{\circ} \mathrm{C}$. The application of a biopreservation system to blood could reduce the microbiological load, extending its shelf life, and thus avoiding immediate processing after blood collection.

\section{ACKNOWLEDGEMENTS}

This study was part of the CAI+D Project financed by Universidad Nacional del Litoral, Santa Fe, Argentina. Laureano S. Frizzo, Lorena P. Soto, María V. Zbrun, and Marcelo L. Signorini are Research Career Members of the Consejo Nacional de Investigaciones Científicas y Técnicas (CONICET, Argentina). Jesica E. Blajman, Ayelén Berisvil, Analía Romero-Scharpen, Eugenia Rossler and Diego M. Astesana are doctoral fellows from CONICET. We would also like to thank Prof Luciana Cignetti (Responsible of English, Faculty of Yeterinary Science, Litoral National University).

\section{REFERENCES}

Barber, L. E. y Deibel, R. H. (1972). Effect of pH and oxygen tension on staphylococcal growth and enterotoxin formation in fermented sausages. Applied Microbiology, 24, 891-898.

Bredholt, S.; Nesbakken, T.; Holck, A. (1999). Protective cultures inhibit growth of Listeria monocytogenes and Escherichia coli O157:H7 in cooked, sliced, vacuum- and gas packaged meat. International Journal of Food Microbiology, 53, 43-52. 
Cogan, T. M.; Beresford, T. P.; Steele, J.; Broadbent, J.; Shah, N. P.; Ustunol, Z. (2007). Invited review: Advances in starter cultures and cultured foods. Journal of Dairy Science, 90(9), 4005-4021.Cotter, P.D., Hill, C., (2003). Surviving the acid test: responses for Grampositive bacteria to low pH. Microbiology and Molecular Biology Reviews, 67 (3), 249-453.

Daeschel, M., (1992). Procedures to detect antimicrobial activities of microorganisms. In: Ray, B., Daeschel, M. (Eds.), Food Biopreservatives of Microbial Origin, CRC Press, New York, pp. 57-80.

Daly, C., Sandine, W. E., Elliker, P. R. (1972). Interactions of food starter cultures and foodborne pathogens. Journal of Milk Food Technology, 35, 349-357.

Dávila, E. (2006). Advances in animal blood processing: development of a biopreservation system and insights on the functional properties of plasma. Doctoral thesis. Institute of Food and Agricultural Technology. Universitat de Girona.

Dávila, E., Saguer, E., Toldra, M., Carretero, C., Pares, D., (2006). Preservation of porcine blood quality by means of lactic acid bacteria. Meat Science, 73, 386-393.

De Vuyst, L. y E. J. Vandamme (1994). Antimicrobial potencial of lactic acid bacteria. En: Bacteriocins of Lactic Acid Bacteria. Microbiology. Genetics and Applications, Pp. 91-143. L-Vuyst, L. y E, J. Vandamme (eds.). Blackie Academic and Professional, Londres.

Holzapfel, W.H., Geisen, R., Schillinger, U., (1995). Biological preservation of foods with reference to protective cultures, bacteriocins and food-grade enzymes. International Journal offood microbiology, 24, 343-362.

Hugas, M. (1998). Bacteriocinogenic lactic acid bacteria for the biopreservation of meat and meat products. Meat Science, 49(S1), 139-150. 
Kołozyn-Krajewskaa, D., Dolatowski, Z. J. (2012). Probiotic meat products and human nutrition. Process Biochemistry, 47, 1761-1772.

Lindgren, S., Dobrogosz, W. (1990). Antagonistic activities of lactic acid bacteria in food and feed fermentations. FEMS Microbiology Review, 87, 149-163.

Lynn Knipe, C. (1988). Production and use of animal blood and blood proteins for human food. In A. M. Pearson \& T. R. Dutson (Eds.). Advances in meat research (Vol. 5, pp. 147165). New York: Elsevier Science Publishers, Ltd.

Márquez, E.; Bracho, M.; Archile, A.; Rangel, L.; Benítez, B. (2005).Proteins, isoleucine, lysine and methionine content of bovine, porcine and poultry blood and their fractions. Food Chemistry, 93, 503-505.

Metaxopoulos, J., Genigeorgis, C., Fanelli, M.J., Franti, C., Cosma, E., (1981). Production of Italian dry salami: effect of starter culture and chemical acidulation on staphylococcal growth in salami under commercial manufacturing conditions. Applied and Environmental Microbiology, 42, 863-871.

MinAgri (Ministerio de Agricultura, Ganadería y Pesca de la Nación), Boletín avícola Anuario 2012(2013). http://www.agroindustria.gob.ar/site/ganaderia/aves/02informes/_archivos/000002-Anuarios/130500_Anuario\%202012\%20(Abril\%202013).pdf O'Sullivan, L., Ross, R.P., Hill, C., (2002). Potential of bacteriocin-producing lactic acid bacteria for improvements in food safety and quality. Biochimie, 84, 593-604.

Ockerman, H.W., Hansen, C.L., (1988). Animal By-Product Processing. Ellis Horwood Ltd, Chichester, England.

Ross, R. P., Morgan, S., and Hill, C. (2002). Preservation and fermentation: past, present and future. International Journal of Food Microbiology, 79(1-2), 3-16. 
Santivarangkna, C., Higl, B., Foerst, P. (2008). Protection mechanisms of sugars during different stages of preparation process of dried lactic acid starter cultures. Food Microbiology, 25(3), 429-441.Schillinger, U., Lucke, F.-K., (1990). Lactic acid bacteria as protective cultures in meat products. Fleischwirtsch, 70, 1296- 1299.

Shelef L.A., (1994). Antimicrobial effects of lactates: A review. Journal of Food Protection, 57(5): 445-450.

Signorini, ML, E Ponce-Alquicira, I Guerrero-Legarreta. (2006). Effect of lactic acid and lactic acid bacteria on growth of spoilage microorganisms in vacuum-packaged beef. Journal of Muscle Foods, 17, 277-290.

Skytta E., Haikara A., Mattila-Sandholm T. (1993). Production and characterization of antibacterial compounds produced by Pediococcus damnosus and Pediococcus pentosaceus. Journal of Applied Bacteriology, 74(2): 134-142.

Vandenbergh, P.A., (1993). Lactic acid bacteria, their metabolic products and interference with microbial growth. FEMS Microbiology Reviews, 12, 221-238.

Zamora Rodriguez, L.M. (2003) Aislamiento, identificación y conservación de cultivos de bacterias lácticas antagonistas de microbiota contaminante de sangre de matadero. Tesis doctoral, Departament d'Enginyeria Química Agraria i Tecnologia Agroalimentària Institut de Tecnologia Agroalimentària. Universitat de Girona. 
Zbrun MV, Altina MG, Bonansea E, Frizzo LS, Soto LP, Romero-Scharpen A, Rosmini MR, Sequeira GJ, Signorini ML (2013). Identification of lactic acid bacteria with bio-preservative potential isolated from contaminated avian blood obtained at the slaughterhouse. Archivos de Medicina Veterinaria, 45, 273-282.

Zbrun M.V. (2014). "Developing a system for avian blood biopreservation collected in slaughterhouses." ”. Ph. D. Thesis, National University of Litoral. 
Table 1. Effect of Biopreservation System (BS) on the growth of Enterobacteriaceae, coliforms, Pseudomonas spp., Staphylococcus aureus and lactic acid bacteria in avian blood stored at $30^{\circ} \mathrm{C}$ for $48 \mathrm{~h}$.

\begin{tabular}{|c|c|c|c|c|c|}
\hline \multirow{2}{*}{ Bacteria group } & \multirow{2}{*}{ Treatment } & \multicolumn{4}{|c|}{ Mean (SD) bacteria count (log ufc/ml) } \\
\hline & & Time $0 \mathrm{~h}$ & Time $24 \mathrm{~h}$ & Time $48 \mathrm{~h}$ & Significance $^{1}, P<$ \\
\hline \multirow[b]{3}{*}{ Enterobacteriaceae } & & & & & \multirow{3}{*}{0.001} \\
\hline & No BS & $5.62(0.03)^{\mathrm{a}}$ & $8.36(0.19)^{\mathrm{a}}$ & $8.34(0.04)^{\mathrm{a}}$ & \\
\hline & With BS & $5.45(0.59)^{\mathrm{a}}$ & $5.70(0.51)^{b}$ & $8.91(0.59)^{\mathrm{a}}$ & \\
\hline \multirow{2}{*}{ Coliforms } & No BS & $5.52(0.39)^{\mathrm{a}}$ & $8.16(0.34)^{\mathrm{a}}$ & $8.23(0.27)^{\mathrm{a}}$ & \multirow[t]{2}{*}{0.001} \\
\hline & With BS & $5.06(0.38)^{b}$ & $5.66(1.04)^{b}$ & $8.78(0.55)^{\mathrm{a}}$ & \\
\hline \multirow{2}{*}{ Pseudomonas spp. } & No BS & $2.48(0.36)^{\mathrm{a}}$ & $6.65(0.63)^{\mathrm{a}}$ & $6.28(0.61)^{\mathrm{a}}$ & \multirow[t]{2}{*}{0.001} \\
\hline & With BS & $2.61(0.41)^{\mathrm{a}}$ & $2.24(0.35)^{b}$ & $5.83(0.18)^{b}$ & \\
\hline \multirow[b]{2}{*}{ Sthaphylococcus aureus } & No BS & $4.92(1.04)^{\mathrm{a}}$ & $6.41(0.53)^{\mathrm{a}}$ & $5.64(0.77)^{\mathrm{a}}$ & \multirow[t]{2}{*}{0.001} \\
\hline & Eith BS & $4.23(0.15)^{\mathrm{a}}$ & $1.96(0.19)^{b}$ & $6.52(1.77)^{\mathrm{a}}$ & \\
\hline \multirow{2}{*}{ Lactic acid bacteria } & No BS & $4.99(0.06)^{\mathrm{a}}$ & $7.93(0.22)^{\mathrm{a}}$ & $7.76(0.09)^{\mathrm{a}}$ & \multirow[t]{2}{*}{0.001} \\
\hline & With BS & $8.98(0.07)^{b}$ & $8.79(0.44)^{b}$ & $8.78(0.40)^{b}$ & \\
\hline
\end{tabular}

${ }^{\mathrm{a}, \mathrm{b}}$ Means within groups with no common superscript letter are significantly $(P<0.05)$.

${ }^{1}$ Significance value of repeated measures (ANOVA). 
Table 2. Mean (SD) effect of Biopreservation System (BS) on the pH in avian blood stored at $30^{\circ} \mathrm{C}$ for $48 \mathrm{~h}$

\begin{tabular}{|l|c|c|c|c|}
\hline \multirow{2}{*}{ Treatments } & Time $0 \mathrm{~h}$ & Time $24 \mathrm{~h}$ & Time $48 \mathrm{~h}$ & Significance ${ }^{1}, P<1$ \\
\cline { 2 - 5 } & & & & \\
\hline No BS & $7.58(0.04)^{\mathrm{a}}$ & $6.88(0.33)^{\mathrm{a}}$ & $7.07(0.13)^{\mathrm{a}}$ & \multirow{2}{*}{0.001} \\
\hline With BS & $6.02(0.18)^{\mathrm{b}}$ & $4.58(0.26)^{\mathrm{b}}$ & $6.67(0.15)^{\mathrm{b}}$ & \\
\hline
\end{tabular}

${ }^{\mathrm{a}, \mathrm{b}}$ Means within groups with no common superscript letter are significantly $(P<0.05)$.

${ }^{1}$ Significance value of repeated measures (ANOVA) 
Table 3. Mean (SD) effect of Biopreservation System (BS) on haemolysis in avian blood stored at $30^{\circ} \mathrm{C}$ for $48 \mathrm{~h}$

\begin{tabular}{|c|c|c|c|c|}
\hline & \multicolumn{3}{|c|}{ Haemolysis (Abs 414nm) } & Significance,$P<$ \\
\hline Treatments & Time $0 \mathrm{~h}$ & Time $24 \mathrm{~h}$ & Time $48 \mathrm{~h}$ & \\
\hline & & & & \\
\hline No BS & $0.23(0.04) \mathrm{a}$ & $0.60(0.27)^{\mathrm{a}}$ & $0.66(0.33)^{\mathrm{a}}$ & \\
\hline With BS & $0.21(0.02)^{\mathrm{a}}$ & $0.26(0.21)^{\mathrm{b}}$ & $0.23(0.19)^{b}$ & \\
\hline
\end{tabular}

${ }^{\mathrm{a}, \mathrm{b}}$ Means within groups with no common superscript letter are significantly $(P<0.05)$.

${ }^{1}$ Significance value of repeated measures (ANOVA)

SD: standard deviation. 